\title{
Article
}

\section{The Association between the Type of Delivery and Factors Associated with Exclusive Breastfeeding Practice among Polish Women-A Cross-Sectional Study}

\author{
Julia Tracz *(D), Danuta Gajewska *(D) and Joanna Myszkowska-Ryciak \\ Department of Dietetics, Institute of Human Nutrition Sciences, Warsaw University of Life Sciences (WULS), \\ 159C Nowoursynowska Str., 02-776 Warsaw, Poland; joanna_myszkowska_ryciak@sggw.edu.pl \\ * Correspondence: julia_tracz@sggw.edu.pl (J.T.); danuta_gajewska@sggw.edu.pl (D.G.)
}

Citation: Tracz, J.; Gajewska, D.; Myszkowska-Ryciak, J. The Association between the Type of Delivery and Factors Associated with Exclusive Breastfeeding Practice among Polish Women-A

Cross-Sectional Study. Int. J. Environ. Res. Public Health 2021, 18, 10987. https://doi.org/10.3390/ ijerph182010987

Academic Editor: Felix Akpojene Ogbo

Received: 27 July 2021

Accepted: 12 October 2021

Published: 19 October 2021

Publisher's Note: MDPI stays neutral with regard to jurisdictional claims in published maps and institutional affiliations.

Copyright: (c) 2021 by the authors. Licensee MDPI, Basel, Switzerland. This article is an open access article distributed under the terms and conditions of the Creative Commons Attribution (CC BY) license (https:/ / creativecommons.org/licenses/by/ $4.0 /)$.

\begin{abstract}
The type of delivery influences breastfeeding, both in terms of initiation and duration. The aim of the study was to determine the association between the type of delivery and factors associated with exclusive breastfeeding (EBF) practice among Polish women. Data on sociodemographic variables, pre-pregnancy weight, height, course of pregnancy, type of delivery and duration of breastfeeding were collected using a Computer-Assisted Web Interview. Of the 1024 breastfeeding women who participated in the study, 59.9\% gave birth vaginally and $40.1 \%$ gave birth by caesarean section. The chance of starting EBF [OR: $0.478 ; 95 \% \mathrm{Cl}: 0.274,0.832$ ] and continuing it for four months [OR: $0.836 ; 95 \% \mathrm{Cl}: 0.569,0.949$ ] was lower in the case of caesarean delivery. Starting EBF was negatively affected by pre-pregnancy overweight status and obesity in the case of caesarean delivery. EBF practice for four months was negatively affected by age [18-24 years and 25-34 years], elementary education and average income [2001-4000 PLN] in the case of caesarean delivery. A negative impact on the chance of EBF for six months was also observed for younger age [18-24 years], elementary and secondary education and average income [2001-4000 PLN] in the case of caesarean delivery. There was no association between starting EBF and age, net income, place of living, pregnancy complications or the child's birth weight category in the case of both subgroups, as well as between education and previous pregnancies in the case of vaginal delivery. These results suggest that women who deliver by caesarean section need additional breastfeeding support.
\end{abstract}

Keywords: exclusive breastfeeding; breastfeeding duration; caesarean delivery; vaginal delivery

\section{Introduction}

Breastfeeding has many proven benefits for both children and mothers. Its protective effect against diarrhoea and respiratory system infection among children is well documented [1]. Breastfeeding reduces the risk of necrotizing enterocolitis and sudden infant death syndrome, as well as the risk of being overweight and obese in adult life [2,3]. Furthermore, breastfeeding is positively associated with a child's intelligence quotient (IQ) [3]. A recent study showed that individuals who breastfed as children were less likely to contract COVID-19. As regards women's health, breastfeeding decreases postpartum blood loss and speeds up involution of the uterus. Breastfeeding promotes a faster return to the pre-pregnancy body mass index [2], and there is an association between breastfeeding and reduced maternal depression [4]. Long-term effects for the mother, such as a lower risk of breast and ovarian cancers, are also proven [2,4]. Breastfeeding women, especially those who exclusively breastfeed, have longer periods of amenorrhoea [4]. It is worth emphasising that breastfeeding is also beneficial to the economy and the environment [5].

The World Health Organization (WHO) and The American Academy of Pediatrics (AAP) consentaneously recommend that children should be exclusively breastfed for the first six months of life $[2,6]$. The Polish Society for Paediatrics Gastroenterology, Hepatology and Nutrition also highlights that exclusive breastfeeding (EBF) for six months should be 
the paramount goal to achieve. In addition, a partial or shorter breastfeeding duration is also beneficial and should be continued as long as it is desired by the mother and the child [7]. Nevertheless, the factual duration of EBF or any breastfeeding is often very far from the recommended standards. The study by Królak-Olejnik et al. showed that the breastfeeding initiation rate in Poland was $97 \%$, whereas the EBF rate at six months was only $4 \%$ [8].

Previous studies have reported that caesarean section is negatively associated with breastfeeding practice $[9,10]$. A prospective cohort study found that caesarean delivery has a negative impact on EBF during the first and third months after delivery but not during the sixth month [11]. More attention should be paid to early breastfeeding after caesarean section to avoid long-term health problems [12]. Unfortunately, an increase in the number of caesarean sections is noticed in many countries, with a rapid expansion in Eastern Europe, Central and South Asia [12]. In Poland, caesarean deliveries accounted for $37.25 \%$ of all deliveries in 2019 [13]. According to the WHO's statement, caesarean sections are beneficial for saving maternal and infant lives but only when medical reasons occur. However, even when more than $10 \%$ of deliveries in a population are by caesarean section, there is still no impact on maternal and newborn mortality [14].

Therefore, factors which can increase the odds of starting EBF should be taken into account during antenatal care. Taking relevant actions among women who deliver the baby by caesarean section might enable them to breastfeed longer. The aim of this study was to determine the association between the type of delivery and factors associated with EBF practice among Polish women.

\section{Materials and Methods}

\subsection{General Information}

Survey data were obtained from 1024 mothers who had breastfed or had been breastfeeding at the time of the data gathering. Data collection was carried out in April 2018 and in May 2018. This study was a part of the educational program for parents, Nestlé Healthy start to the future, which was coordinated by the Polish Society of Dietetics with the participation of the IQS Agency (a Polish research-analytics company, Warsaw, Poland). A detailed research methodology has been described in previously published articles on dietary habits and nutritional status of women during pregnancy and breastfeeding [15] and factors influencing the duration of breastfeeding [16]. The study was conducted in accordance with the Declaration of Helsinki.

\subsection{Study Participants and Collecting Data}

Eligibility criteria were: being an adult ( $\geq 18$ years old), a breastfeeding woman and being a mother of an infant or a toddler aged 6-18 months. Exclusion criteria included being pregnant, being a woman who has never breastfed, being the mother of an infant aged $<6$ months or a toddler aged over 18 months.

The study was conducted using the Computer-Assisted Web Interview (CAWI). The tool used to carry out the research was a questionnaire. Respondents were asked to complete the individual electronic form on the web panel (Opinie.pl) belonging to the independent external research agency, IQS. This web panel has existed since 2007. Currently, it has 110,000 active users including 10,500 mothers of children born between 2015-2018. Participation in the study was anonymous and voluntary, and women were not compensated for the participation. The research company provided the sampling frame and the IT tools needed for the fieldwork. The time for filling out the questionnaire did not exceed $15 \mathrm{~min}$.

Sociodemographic data such as the woman's age (open-ended question), education, number of persons in the household, place of living and net household income were collected.

Some socio-demographic variables were re-categorized prior to analyses. Age was re-categorized into three categories: "18-24 years"; "25-34 years"; and "over 35 years". Education level was re-categorized into three categories: "elementary", "secondary" and 
"tertiary". Place of living was re-categorized into three categories based on the divisions presented in basic urban statistics from 2016: "rural area/farm"; "town < 99,000 inhabitants"; and "city with over 100,000 inhabitants" [17]. Net household income was categorized in line with a minimum salary and an average wage in Poland in 2018 into three categories: " $\leq 2000$ PLN"; “2001-4000 PLN"; “ $\geq 4001$ PLN" [18].

Self-reported pre-pregnancy weight and height were used to calculate pre-pregnancy Body Mass Index (BMI). Pre-pregnancy BMI was calculated according to the following equation: person's weight in kilograms divided by the square of the person's height in meters. In accordance with the WHO classification, four BMI categories were defined: underweight $\left(<18.5 \mathrm{~kg} / \mathrm{m}^{2}\right)$; normal body weight $\left(18.5-24.9 \mathrm{~kg} / \mathrm{m}^{2}\right)$; overweight $\left(25-29.9 \mathrm{~kg} / \mathrm{m}^{2}\right)$ and obesity $\left(>30 \mathrm{~kg} / \mathrm{m}^{2}\right)$ [19]. Then, pre-pregnancy BMI was re-categorized into four groups: "underweight", "normal body weight", "overweight/obesity" and "no data".

In the question on the course of pregnancy, women chose between "proper course of pregnancy" or "complicated course of pregnancy". Respondents were asked whether it was their first pregnancy ("yes" or "no") and whether their child was born "in due date", "as a premature baby" or "after due date". Women were asked to provide the birth weight of their child (open-ended question). The birth weight of the child was categorized into three groups: "low birth weight" - <2500 g, "normal birth weight" - 2500-4000 g and "high birth weight" $\longrightarrow 4000 \mathrm{~g}$ [20].

Participants were asked whether they had "a vaginal birth", "a planned caesarean delivery" or "an unplanned caesarean delivery". According to the type of delivery, all respondents were divided into two groups: "women with vaginal birth" and "women with caesarean delivery".

Women were questioned about the duration of breastfeeding ("less than one month"; "one month"; "two months"; "three months"; "four months"; "five months"; "six months"; "seven months"; "eight months"; "nine months"; "ten months"; "twelve months" or "longer than one year") and EBF ("I wasn't exclusively breastfeeding"; "less than one month"; "one month"; "two months"; "three months"; "four months"; "five months" and "six months". EBF was defined as feeding the infant with only breastmilk without any solids or liquids [21]. Duration of EBF was re-categorized into three categories: "starting EBF"; "EBF for four months"; "EBF for six months".

\subsection{Statistical Analysis}

All data were analysed using STATISTICA version 13.1 (Copyright@StatSoft, Inc., 1984-2014, Cracow, Poland). Data were analysed in the groups of women with vaginal delivery (VD) and caesarean delivery (CD) in terms of age, level of education, place of living, net household income, pre-pregnancy body weight status, number of pregnancies, time of delivery, course of pregnancy and EBF duration. The normality of distribution of quantitative data was checked using the Shapiro-Wilk test. Variables not normally distributed were tested with the Mann-Whitney U test. Statistical significances for nominal (categorical) variables were determined using the Pearson's chi-square test. An odds ratio (the Wald test) with $95 \%$ confidence intervals (95\% CI) was calculated using logistic regression analysis to study the relationship between method of delivery and breastfeeding duration. The significance level for all statistical analyses was considered at $p \leq 0.05$.

\section{Results}

\section{Characteristics of the Study Group}

The total sample group consisted of 1024 women aged between 18 and 50 years old (average age was 30.6). Of all the participating women, 613 (59.9\%) gave birth vaginally and $411(40.1 \%)$ gave birth by caesarean section. There were no significant differences in the mean age ( $30.8 \pm 7.4$ vs. $30.3 \pm 6.6 ; p=0.552)$ and mean pre-pregnancy BMI $(23.3 \pm 6.0$ vs. $23.8 \pm 6.3 ; p=0.200$ ) between these two subgroups. The overall characteristics of the study sample are displayed in Table 1. All data are expressed as number values and in percentages. 
Table 1. Demographic characteristics and gestational information in the subgroups depending on the method of delivery $(n=1024)$.

\begin{tabular}{|c|c|c|c|}
\hline \multirow[b]{2}{*}{ Characteristic ${ }^{1}$} & \multicolumn{2}{|c|}{ Method of Delivery } & \multirow[b]{2}{*}{$p$-Value ${ }^{2}$} \\
\hline & $\begin{array}{l}\text { Vaginal } \\
n=613\end{array}$ & $\begin{array}{c}\text { Caesarean } \\
n=411\end{array}$ & \\
\hline \multicolumn{4}{|l|}{ Age [years] } \\
\hline $18-24$ & 139 (22.7) & $88(21.4)$ & \multirow{3}{*}{0.183} \\
\hline $25-34$ & $265(43.2)$ & $201(48.9)$ & \\
\hline$\geq 35$ & $209(34.1)$ & $122(29.7)$ & \\
\hline \multicolumn{4}{|l|}{ Education } \\
\hline Elementary & $91(14.8)$ & $59(14.3)$ & \multirow{3}{*}{0.105} \\
\hline Secondary & $221(36.0)$ & $124(30.2)$ & \\
\hline Tertiary & $301(49.1)$ & $228(55.5)$ & \\
\hline \multicolumn{4}{|l|}{ Place of residence } \\
\hline Rural area/farm & $238(38.8)$ & $174(42.3)$ & \multirow{3}{*}{0.481} \\
\hline Town $\leq 99,000$ inhabitants & $189(30.8)$ & $115(28.0)$ & \\
\hline City $\geq 100,000$ inhabitants & $186(30.3)$ & $122(29.7)$ & \\
\hline \multicolumn{4}{|l|}{ Net Income } \\
\hline$\leq 2000$ PLN 3 & $81(13.2)$ & $59(14.4)$ & \multirow{4}{*}{0.795} \\
\hline 2001-4000 PLN & $181(29.5)$ & $122(29.7)$ & \\
\hline$\geq 4001$ PLN & $302(49.3)$ & $192(46.7)$ & \\
\hline No answer & $49(8.0)$ & $38(9.2)$ & \\
\hline \multicolumn{4}{|l|}{ Pre-pregnancy BMI $\left[\mathrm{kg} / \mathrm{m}^{2}\right]$} \\
\hline Underweight & $31(5.1)$ & $26(6.3)$ & \multirow{4}{*}{0.197} \\
\hline Normal & $346(56.4)$ & $208(50.6)$ & \\
\hline Overweight/obesity & $210(34.3)$ & $163(39.7)$ & \\
\hline No data & $26(4.2)$ & $14(3.4)$ & \\
\hline \multicolumn{4}{|l|}{ Primipara } \\
\hline No & $304(49.6)$ & $187(45.5)$ & 0.199 \\
\hline \multicolumn{4}{|l|}{ Pregnancy Complications } \\
\hline Yes & $40(6.5)$ & $54(13.1)$ & $<0.001 *$ \\
\hline
\end{tabular}

${ }^{1}$ Data are given as No. (\%) unless otherwise indicated. Some percentages do not total 100 because of rounding; ${ }^{2} \mathrm{Chi}^{2}$ Pearson test vaginal vs. caesarean delivery; ${ }^{3}$ PLN (Polish New Zloty) $=\sim 0.23$ Euro; * statistically significant difference.

There were no significant differences in the majority of the analysed variables-namely, age, education, place of living, net income, pre-pregnancy BMI and previous pregnanciesexcept for pregnancy complications. As was expected, the prevalence of pregnancy complications was higher in women who gave birth by caesarean section. Table 2 shows the relationship between the practice of EBF and the type of delivery. Significant differences were observed for the starting EBF and EBF for four months by the type of delivery. In the case of women giving birth by caesarean section, the chance of starting EBF was nearly half as high compared to women giving birth naturally. Similarly, the chance of continuing EBF for four months was lower by approximately $25 \%$ in the case of caesarean delivery. However, no differences were observed for the prevalence and odds ratio for EBF for six months between the two analysed subgroups. 
Table 2. The odds ratio (OR) for exclusive breastfeeding (EBF) practice depending on the method of delivery $(n=1024)$.

\begin{tabular}{|c|c|c|c|}
\hline \multirow[b]{2}{*}{ Characteristic $^{1}$} & \multicolumn{2}{|c|}{ Method of Delivery } & \multirow[b]{2}{*}{$p$-Value } \\
\hline & $\begin{array}{l}\text { Vaginal } \\
n=613\end{array}$ & $\begin{array}{c}\text { Caesarean } \\
n=411\end{array}$ & \\
\hline Starting EBF & $590(96)$ & $380(92)$ & \multirow{2}{*}{$0.008 *$} \\
\hline OR $[95 \% \mathrm{CI}]$ & 1 ref. & $0.478[0.274-0.832]$ * & \\
\hline EBF for 4 months & $394(64)$ & $234(57)$ & \multirow{2}{*}{$0.018^{*}$} \\
\hline OR $[95 \% \mathrm{CI}]$ & 1 ref. & $0.735[0.569-0.949]$ * & \\
\hline EBF for 6 months & $220(36)$ & $131(32)$ & \multirow{2}{*}{0.185} \\
\hline OR [95\% CI] & 1 ref. & 0.836 [0.641-1.089] & \\
\hline
\end{tabular}

${ }^{1}$ Data are given as No. (\%) unless otherwise indicated. Some percentages do not total 100 because of rounding,

${ }^{2} \mathrm{Chi}^{2}$ Pearson test vaginal vs. caesarean delivery; ${ }^{*}$ statistically significant difference.

Statistical analysis (the chi-squared test) provided more detailed information on the association between respondents' characteristics, method of delivery and EBF practice (Table 3). Starting EBF was related to education, pre-pregnancy BMI and earlier pregnancies, but only in the case of women who gave birth by caesarean section. There was no association between starting EBF and age, net income, place of living, pregnancy complications or the child's birth weight category in the case of both subgroups, as well as between education and previous pregnancies in the case of vaginal delivery. Continuation of EBF for four months was related to age, education and net income, both in the case of women giving birth vaginally and by caesarean section. Significant relationships between EBF and age and education were also observed in both subgroups at six months.

For further statistical analyses (logistic regression), the variables that significantly differentiated the EBF practice in two subgroups were selected, namely: age, education, net income, pre-pregnancy BMI and previous pregnancies (Table 4). In the case of vaginal delivery, none of the examined variables influenced the odds ratio for EBF initiation. On the contrary, significant relationships were observed in the case of caesarean section: the chance of starting EBF was over three times higher among multiparous women and women with secondary education. However, excessive pre-pregnancy body weight reduced the odds ratio of breastfeeding to $34 \%$ in this subgroup. Overweight status or obesity before pregnancy also reduced the chance of continuing EBF for four months among women with vaginal delivery. Younger age (18-24 years old) significantly reduced the chance of EBF for four and six months, both in the case of vaginal delivery and caesarean section. In the case of the latter, women aged 25-34 also had about a 50\% lower odds ratio of continuing EBF for four months. A negative impact on the chance of EBF for four and six months was also observed for elementary education in both subgroups. Moreover, the odds ratio for breastfeeding for six months was halved for women with a caesarean delivery and secondary education level. Although the level of income had no effect on the chance of starting EBF, some relationships were observed with the continuation of breastfeeding practice. The lowest net incomes nearly halved the odds ratio for four months of EBF in the case of natural delivery, while no such effect was observed for caesarean delivery. On the contrary, in the case of caesarean delivery, the average income category significantly reduced the chance of EBF for four and six months. 
Table 3. Factors associated with exclusive breastfeeding (EBF) practice depending on the method of delivery $(n=1024)$.

\begin{tabular}{|c|c|c|c|c|c|c|c|c|c|c|c|c|}
\hline \multirow{3}{*}{ Characteristic $^{1}$} & \multicolumn{4}{|c|}{ Starting EBF } & \multicolumn{4}{|c|}{ EBF for 4 Months } & \multicolumn{4}{|c|}{ EBF for 6 Months } \\
\hline & \multicolumn{2}{|c|}{ Vaginal } & \multicolumn{2}{|c|}{ Caesarean } & \multicolumn{2}{|c|}{ Vaginal } & \multicolumn{2}{|c|}{ Caesarean } & \multicolumn{2}{|c|}{ Vaginal } & \multicolumn{2}{|c|}{ Caesarean } \\
\hline & $n=590$ & $p$-Value ${ }^{2}$ & $n=380$ & $p$-Value ${ }^{2}$ & $n=394$ & $p$-Value ${ }^{2}$ & $n=224$ & $p$-Value ${ }^{2}$ & $n=220$ & $p$-Value ${ }^{2}$ & $n=121$ & $p$-Value ${ }^{2}$ \\
\hline \multicolumn{13}{|l|}{ Age [years] } \\
\hline $18-24$ & $132(22)$ & & $81(21)$ & & $69(17)$ & & $35(15)$ & & $33(15)$ & & $14(11)$ & \\
\hline $25-34$ & $256(43)$ & 0.663 & $184(48)$ & 0.659 & $172(44)$ & $<0.001$ * & $113(48)$ & $<0.001$ * & $99(45)$ & $0.002 *$ & $71(54)$ & $0.001 *$ \\
\hline$\geq 35$ & $202(34)$ & & $115(30)$ & & $153(39)$ & & $86(37)$ & & $88(40)$ & & $46(35)$ & \\
\hline \multicolumn{13}{|l|}{ Education } \\
\hline Elementary & $88(15)$ & & $56(15)$ & & $44(11)$ & & $19(8)$ & & $19(9)$ & & $10(8)$ & \\
\hline Tertiary & $289(49)$ & & $204(54)$ & & $209(53)$ & & $144(62)$ & & $124(56)$ & & $90(69)$ & \\
\hline \multicolumn{13}{|l|}{ Place of residence } \\
\hline Rural area/farm & $229(39)$ & & $156(41)$ & & $151(38)$ & & $88(38)$ & & $77(35)$ & & $50(38)$ & \\
\hline Town $\leq 99,000$ inhabitants & $182(31)$ & 0.999 & $109(29)$ & 0.181 & $124(31)$ & 0.894 & $69(29)$ & 0.074 & $75(34)$ & 0.283 & $39(30)$ & 0.503 \\
\hline City $\geq 100,000$ inhabitants & $179(30)$ & & $115(30)$ & & $119(30)$ & & $77(33)$ & & $68(31)$ & 0.200 & $42(32)$ & 0.000 \\
\hline \multicolumn{13}{|l|}{ Net Income } \\
\hline$\leq 2000 \mathrm{PLN}^{3}$ & $77(13)$ & & $56(15)$ & & $42(11)$ & & $32(14)$ & & $23(10)$ & & $17(13)$ & \\
\hline 2001-4000 PLN & $174(29)$ & & $112(29)$ & & $124(31)$ & & $57(24)$ & & $65(29)$ & & $30(23)$ & \\
\hline$\geq 4001$ PLN & $292(49)$ & 0.919 & $178(47)$ & 0.780 & $200(51)$ & $0.038^{*}$ & $126(54)$ & $0.007^{*}$ & $118(54)$ & 0.217 & $70(54)$ & 0.137 \\
\hline Underweight & $29(5)$ & & $25(7)$ & & $16(4)$ & & $12(5)$ & & $11(5)$ & & $6(5)$ & \\
\hline Normal & $338(57)$ & & $199(52)$ & & $236(60)$ & & $126(54)$ & & $129(59)$ & & $74(56)$ & \\
\hline Overweight/obesity & $199(34)$ & 0.171 & $144(38)$ & $0.037^{*}$ & $125(32)$ & 0.087 & $90(38)$ & 0.297 & $69(31)$ & 0.660 & $48(37)$ & 0.336 \\
\hline No Data & $24(4)$ & & $12(3)$ & & $17(4)$ & & $6(3)$ & & $11(5)$ & & $3(2)$ & \\
\hline \multicolumn{13}{|l|}{ Primipara } \\
\hline No & $293(50)$ & 0.863 & $181(48)$ & $0.002 *$ & $198(50)$ & 0.660 & $113(48)$ & 0.191 & $119(54)$ & 0.095 & $64(49)$ & 0.350 \\
\hline Pregnancy Complications & & & & & & & & & & & & \\
\hline No & $554(94)$ & 0.068 & $331(87)$ & 0.608 & $373(95)$ & 0.108 & $207(88)$ & 0.269 & $211(96)$ & 0.068 & $117(89)$ & 0.314 \\
\hline \multicolumn{13}{|l|}{ Birth weight category } \\
\hline LBW & $22(4)$ & & $32(8)$ & & $14(4)$ & & $16(7)$ & & $7(3)$ & & $10(8)$ & \\
\hline NBW & $510(86)$ & 0.678 & $301(79)$ & 0.657 & $342(87)$ & 0.941 & $190(81)$ & 0.270 & $190(86)$ & 0.761 & $105(80)$ & 0.858 \\
\hline HBW & $58(10)$ & & 47 (12) & & $38(10)$ & & $28(12)$ & & $23(10)$ & & $16(12)$ & \\
\hline
\end{tabular}

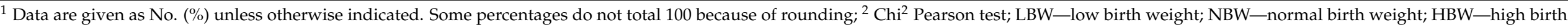

weight; ${ }^{3}$ PLN (Polish New Zloty) $=\sim 0.23$ Euro; ${ }^{*}$ statistically significant difference. 
Table 4. The odds ratio (OR) for exclusive breastfeeding (EBF) practice depending on the method of delivery $(n=1024)$.

\begin{tabular}{|c|c|c|c|c|c|c|}
\hline \multirow{2}{*}{ Characteristic $^{1}$} & \multicolumn{2}{|c|}{$\begin{array}{l}\text { Starting EBF } \\
\text { OR }[95 \% \mathrm{CI}]\end{array}$} & \multicolumn{2}{|c|}{$\begin{array}{l}\text { EBF for } 4 \text { Months } \\
\text { OR }[95 \% \mathrm{CI}]\end{array}$} & \multicolumn{2}{|c|}{$\begin{array}{l}\text { EBF for } 6 \text { Months } \\
\text { OR }[95 \% \mathrm{CI}]\end{array}$} \\
\hline & $\begin{array}{l}\text { Vaginal } \\
n=590\end{array}$ & $\begin{array}{c}\text { Caesarean } \\
n=380\end{array}$ & $\begin{array}{l}\text { Vaginal } \\
n=372\end{array}$ & $\begin{array}{c}\text { Caesarean } \\
n=224\end{array}$ & $\begin{array}{l}\text { Vaginal } \\
n=198\end{array}$ & $\begin{array}{c}\text { Caesarean } \\
n=121\end{array}$ \\
\hline \multicolumn{7}{|l|}{ Age [years] } \\
\hline $18-24$ & $0.653[0.224-1.906]$ & $0.704[0.238-2.086]$ & $0.361[0.230-0.567]^{*}$ & $0.276[0.155-0.493]^{*}$ & $0.428[0.266-0.690]^{*}$ & $0.313[0.159-0.616]$ * \\
\hline $25-34$ & $0.986[0.361-2.692]$ & $0.659[0.265-1.638]$ & $0.677[0.455-1.007]$ & $0.538[0.333-0.867]$ * & $0.820[0.566-1.188]$ & $0.902[0.566-1.439]$ \\
\hline$\geq 35$ & 1 ref. & 1 ref. & 1 ref. & 1 ref. & 1 ref. & 1 ref. \\
\hline \multicolumn{7}{|l|}{ Education } \\
\hline Elementary & $1.218[0.336-4.414]$ & $2.196[0.638-7.560]$ & $0.412[0.255-0.665]^{*}$ & $0.277[0.151-0.509] *$ & $0.377[0.216-0.656]]^{*}$ & $0.313[0.151-0.649]$ * \\
\hline Secondary & $1.106[0.444-2.752]$ & $3.529[1.196-10.417]$ * & $0.776[0.537-1.121]$ & $0.781[0.500-1.221]$ & $0.763[0.533-1.093]$ & $0.511[0.315-0.831]^{*}$ \\
\hline Tertiary & 1 ref. & 1 ref. & 1 ref. & 1 ref. & 1 ref. & 1 ref. \\
\hline \multicolumn{7}{|l|}{ Net Income } \\
\hline$\leq 2000$ PLN $^{3}$ & $0.688[0.225-2.101]$ & 1.468 [0.407-5.294] & $0.549[0.334-0.903]$ * & $0.621[0.343-1.123]$ & $0.613[0.362-1.056]$ & 0.705 [0.374-1.332] \\
\hline $2001-4000$ PLN & $0.838[0.306-2.291]$ & $0.881[0.378-2.051]$ & $1.109[0.748-1.645]$ & $0.459[0.289-0.730]^{*}$ & $0.874[0.597-1.280]$ & $0.568[0.343-0.943]^{*}$ \\
\hline$\geq 4001$ PLN & 1 ref. & 1 ref. & 1 ref. & 1 ref. & 1 ref. & 1 ref. \\
\hline \multicolumn{7}{|c|}{ Pre-pregnancy BMI $\left[\mathrm{kg} / \mathrm{m}^{2}\right]$} \\
\hline Overweight/obesity & 0.428 [0.169-1.082] & $0.343[0.151-0.779]^{*}$ & $0.685[0.480-0.979]$ * & $0.802[0.530-1.216]$ & $0.823[0.574-1.181]$ & $0.756[0.487-1.174]$ \\
\hline \multicolumn{7}{|l|}{ Primipara } \\
\hline Yes & 1 ref. & 1 ref. & 1 ref. & 1 ref. & 1 ref. & 1 ref. \\
\hline No & $1.076[0.467-2.478]$ & $3.790[1.520-9.448]$ * & 1.077 [0.774-1.499] & 1.300 [0.877-1.927] & $1.325[0.951-1.844]$ & $1.219[0.804-1.848]$ \\
\hline
\end{tabular}

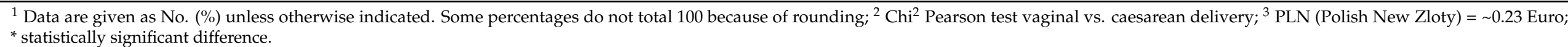


Figure 1 shows the percentage of women who declared breastfeeding, including EBF, during the first six months after labour depending on the type of delivery. Breastfeeding was more prevalent among women who had a vaginal delivery compared to women who had a caesarean section. The same relationship was observed in the case of EBF. It is worth noting that by the fourth month, the rate of decline in the percentage of breastfeeding and exclusively breastfeeding women was similar. However, after four months, a faster decline in the percentage of exclusively breastfeeding women was observed. Interestingly, this decrease was more pronounced in the case of vaginal delivery compared to the caesarean section delivery.

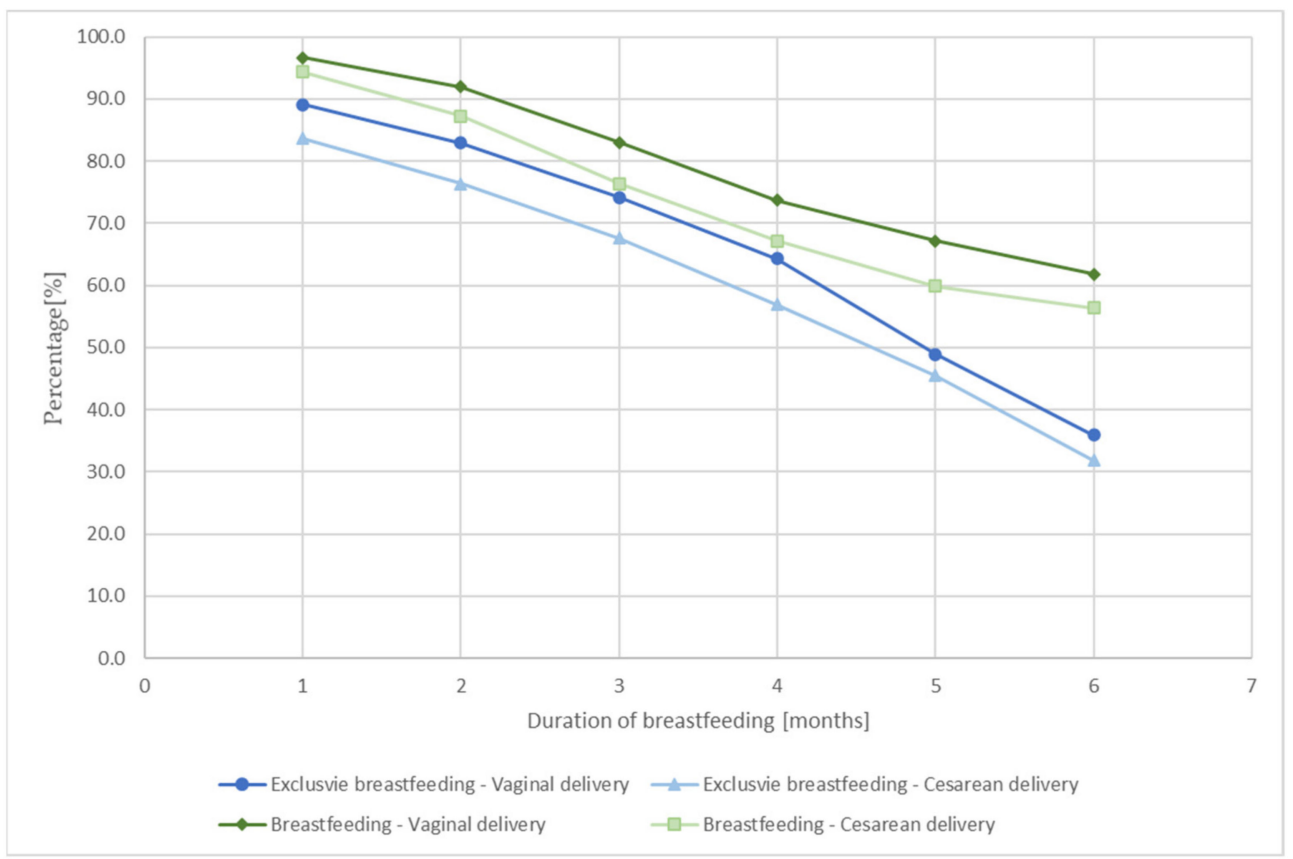

Figure 1. Duration of breastfeeding and exclusive breastfeeding in the case of vaginal delivery and caesarean delivery.

\section{Discussion}

EBF is the optimal way of feeding infants for six months of their lives. In this study, we investigated factors which can influence starting EBF and its duration in the case of caesarean section. Age, education, net income, pre-pregnancy BMI and previous pregnancies were significantly associated with EBF among women who delivered by caesarean section.

Our results showed that caesarean delivery had an impact on starting EBF and EBF at four months but not at six months after delivery. Caesarean delivery was negatively associated with the early EBF practice. Overall, these findings are in accordance with results reported by previous authors [11,22]. In the study by Hobbs et al., women who delivered by caesarean section were less likely to initiate breastfeeding and more likely to cease breastfeeding at four months postpartum [23]. A systematic review and metaanalysis of 53 studies concerning breastfeeding after caesarean section found that the rate of early breastfeeding after caesarean section was lower than after vaginal delivery [24]. However, it was reported that only the induced vaginal delivery and emergency caesarean section were associated with lower rates of breastfeeding at four weeks and at six months, respectively, which might have resulted from the better preparation taken by mothers who had a planned caesarean section [25]. In the present study, the proportion of caesarean sections was slightly higher (40.1\%) than in previously published data (37.2\%) [13]. High rates of caesarean sections should be an alarming issue, especially when breastfeeding practice is considered. Firstly, there is a need for familiarising women with benefits and risks of vaginal delivery as well as caesarean section. In Poland, women's knowledge in 
this area is insufficient [26]. Secondly, health care professionals should provide mothers who deliver by caesarean section with additional breastfeeding support. This support should cover help from the midwife and the nurse, as well as physical and psychological support. In addition, dietary counselling should be provided to advise on an appropriate diet for breastfeeding women. This support should comply with those mothers' special needs, which are caused by caesarean section.

In our study, women with secondary education who delivered by caesarean section were more likely to start EBF in this subgroup. However, we found that secondary education lowered the odds ratio of breastfeeding at six months, whereas Lio et al. found that women with medium education had higher chances of EBF for six months [27]. A difference between these results can be attributed to the fact that, in Poland, a long break at work among better educated women might worsen their position on the labour market [28]. Moreover, elementary education was associated with a lower chance of EBF both at four and six months, respectively. These results are consistent with previous studies wherein lower education increased the risk of early cessation of breastfeeding [29-32]. In the study by Logan et al., women with more than 12 years of education had increased odds of initiation and duration of breastfeeding. Early breastfeeding cessation was associated with a lower education level. Among mothers with a lower level of education, rates of smoking, overweight status and obesity, and elective caesarean section were higher [33]. Heck et al. suggested that both maternal and paternal education is correlated with starting breastfeeding. Parents with higher educational levels are more likely to comprehend benefits of breastfeeding [34]. Furthermore, our study indicated that a lower income decreased the chance of continuing EBF for four months in the case of vaginal delivery, whereas an average income decreased the odds ratio of EBF for four and six months in the case of caesarean section. However, Economou et al. found that a higher family income was a determinant of breastfeeding but not of EBF [35]. In another study, women with a higher socioeconomic status were less likely to stop EBF in the early postpartum period [36]. Intervention aimed at prolonging breastfeeding duration must consider the level of education of women regardless of the type of delivery. Furthermore, developing programmes directed to both parents could also be beneficial.

According to Simko et al., a higher risk of caesarean section was associated with pre-pregnancy obesity [37]. Obese women have double the risk of caesarean delivery [38]. Other authors pointed out that an overweight status and obesity were associated with complications such us as gestational diabetes, gestational hypertension, preeclampsia, preterm birth, caesarean delivery and macrosomia [39]. In our study, the odds ratios of starting breastfeeding were lower for those women with an overweight status or obesity who delivered by caesarean section. Contrary to our results, in the study by de Jersey et al., caesarean delivery in both women who were a normal weight and overweight was negatively associated with EBF at discharge from hospital [40]. However, in the Australian cohort, the risk of unsuccessful starting EBF was associated with pre-pregnancy obesity [41]. Recently, authors of the systematic review and meta-analysis indicated that overweight and obese women have lower chances of starting breastfeeding. The likelihood of EBF among this subgroup is also lower [42]. Our results are consistent with these findings, since chances of continuing EBF for four months among obese or overweight women with vaginal delivery were decreased. A nationwide study found that elevated BMI was widespread among Polish women at childbearing age [43]. Simultaneously, according to the European Perinatal Report, more than $10 \%$ of women in countries with pre-pregnancy BMI data were obese at the beginning of pregnancy [44]. It may suggest that decreasing rates of overweight status and obesity among women at reproductive age might positively affect peripartum period as well as breastfeeding practice.

A previous study showed that women older than 34 years were more likely to have a caesarean section [10]. However, in our study, only $30 \%$ of women delivered by caesarean section were older than 34 years of age. In our study, the odds ratio of EBF for four months was lower for younger women regardless of the mode of delivery. Women aged 18-24 were 
less likely to exclusively breastfeed for six months. In the study by Lande et al., the chance of EBF at four and six months was higher with an increased maternal age [45]. Other authors showed that the older maternal age of $\geq 35$ and primipara were negative factors of success for EBF initiation [46]. In our study, multiparous women had a higher chance of starting EBF in the case of caesarean section. A study among Canadian women found an association between EBF for six months and factors such as living with a partner, older age at pregnancy, lower pre-pregnancy weight and being multipara. Women with earlier pregnancies might have a valuable experience in breastfeeding [47]. Previous successful breastfeeding experience and observation are positive determinants for breastfeeding [48]. Based on our findings, women who give birth for the first time, especially by caesarean section, should receive additional breastfeeding support.

The strengths of this study include a large, nationwide sample size. However, this study has some limitations. Firstly, the Computer-Assisted Web Interview might increase the possibility of receiving low quality answers. Secondly, there is a risk that self-reported weight and height could be understated or overestimated. Furthermore, inclusion criteria might be considered as a limitation of our study. There is a lack of data about women who did not start breastfeeding, since only women who initiated breastfeeding were included in this study. Moreover, this is an observational study: relationships are observed, but cause and effect conclusions cannot be drawn.

\section{Conclusions}

In conclusion, our findings confirmed that among lactating women, any breastfeeding and exclusive breastfeeding are more prevalent in the case of vaginal delivery compared to caesarean section. Overall, variables such as age, education, net income, pre-pregnancy $\mathrm{BMI}$ and previous pregnancies were significantly associated with exclusive breastfeeding among women who delivered by caesarean section. The results highlighted that more attention should be devoted to women who deliver by caesarean section in relation to breastfeeding. Additional breastfeeding support might be notably needed in this group. Taking relevant actions among women who deliver the baby by caesarean section might enable them to breastfeed longer. Furthermore, these findings might be valuable for healthcare professionals to develop strategies that are targeted at promoting breastfeeding in this group.

In conclusion, our results confirmed a high prevalence of caesarean section deliveries among Polish women, as well as a large decrease in the percentage of women exclusively breastfeeding during the first six months after delivery. This decrease was particularly noticeable after the fourth month following delivery. These findings highlight that breastfeeding support and promotion of exclusively breastfeeding should be directed to all women after delivery. Pregnant women and subsequently breastfeeding mothers should be under therapeutic team care.

Author Contributions: Conceptualization, D.G.; methodology, D.G. and J.M.-R.; investigation, D.G.; data curation, D.G., J.T. and J.M.-R.; writing—original draft preparation, J.T.; writing-review and editing, D.G., J.T. and J.M.-R.; visualization, J.T.; supervision, D.G.; project administration, D.G. All authors have read and agreed to the published version of the manuscript.

Funding: This research was funded by Nestlé Polska S.A. The study was a part of the educational program for parents, Nestlé Healthy start to the future, which was coordinated by the Polish Society of Dietetics with the participation of the IQS agency. The article was financed by the Polish Ministry of Science and Higher Education with funds from the Institute of Human Nutrition Sciences, Warsaw University of Life Sciences (WULS), for scientific research.

Institutional Review Board Statement: The study was conducted according to the guidelines of the Declaration of Helsinki.

Informed Consent Statement: Patient consent was waived due to the fact that the research was non-invasive (survey on internet panel) and details of the participants remained undisclosed. The data were collected by CAWI method. 


\section{Data Availability Statement: Not applicable.}

Conflicts of Interest: The authors declare no conflict of interest. The funders had no role in the design of the study; in the collection, analyses, or interpretation of data; in the writing of the manuscript; or in the decision to publish the results.

\section{References}

1. Horta, B.L.; Victora, C.G. Short-Term Effects of Breastfeeding: A Systematic Review on the Benefits of Breastfeeding on Diarrhoea and Pneumonia Mortality; World Health Organization: Geneva, Switzerland, 2013.

2. American Academy of Pediatrics, Section on breastfeeding Breastfeeding and the Use of Human Milk. Pediatrics 2012, 129, e827-e841. [CrossRef]

3. Horta, B.L.; Victora, C.G. Long-Term Effect of Breastfeeding: A Systematic Review; World Health Organization: Geneva, Switzerland, 2013.

4. Victora, C.G.; Bahl, R.; Barros, A.J.D.; França, G.V.A.; Horton, S.; Krasevec, J.; Murch, S.; Sankar, M.J.; Walker, N.; Rollins, N.C. Breastfeeding in the 21st Century: Epidemiology, Mechanisms, and Lifelong Effect. Lancet 2016, 387, 475-490. [CrossRef]

5. Rollins, N.C.; Bhandari, N.; Hajeebhoy, N.; Horton, S.; Lutter, C.K.; Martines, J.C.; Piwoz, E.G.; Richter, L.M.; Victora, C.G. Why Invest, and What It Will Take to Improve Breastfeeding Practices? Lancet 2016, 387, 491-504. [CrossRef]

6. World Health Organization. Nutrition for Health and Development Guideline. In Guideline: Implementing Effective Actions for Improving Adolescent Nutrition; WHO: Geneva, Switzerland, 2017; ISBN 978-92-4-155008-6.

7. Szajewska, H.; Socha, P.; Horvath, A.; Rybak, A.; Zalewski, B.M.; Nehring-Gugulska, M.; Mojska, H.; Czerwionka-Szaflarska, M.; Gajewska, D.; Helwich, E.; et al. Zasady żywienia zdrowych niemowląt. Stanowisko Polskiego Towarzystwa Gastroenterologii, Hepatologii i Żywienia Dzieci. Pediatria 2021, 11, 321-338.

8. Królak-Olejnik, B.; Błasiak, I.; Szczygieł, A. Promotion of Breastfeeding in Poland: The Current Situation. J. Int. Med. Res. 2017, 45, 1976-1984. [CrossRef]

9. Karlström, A.; Lindgren, H.; Hildingsson, I. Maternal and Infant Outcome after Caesarean Section without Recorded Medical Indication: Findings from a Swedish Case-Control Study. BJOG: Int. J. Obstet. Gynaecol. 2013, 120, 479-486. [CrossRef] [PubMed]

10. Palla, H.; Krisantas, P. Mode of Delivery and Breastfeeding Practices. Int. J. Pregnancy Child. Birth 2017, 2, 167-172. [CrossRef]

11. Chen, C.; Yan, Y.; Gao, X.; Xiang, S.; He, Q.; Zeng, G.; Liu, S.; Sha, T.; Li, L. Effects of Cesarean Delivery on Breastfeeding Practices and Duration: A Prospective Cohort Study. J. Hum. Lact. 2018, 34, 526-534. [CrossRef]

12. Boerma, T.; Ronsmans, C.; Melesse, D.Y.; Barros, A.J.D.; Barros, F.C.; Juan, L.; Moller, A.-B.; Say, L.; Hosseinpoor, A.R.; Yi, M.; et al. Global Epidemiology of Use of and Disparities in Caesarean Sections. Lancet 2018, 392, 1341-1348. [CrossRef]

13. Statystyki NFZ. Available online: https://Statystyki.Nfz.Gov.Pl/Benefits /1a?S.Section=N+-+Po $\% C 5 \% 820 \% C 5 \% B C n i c t w o+i+$ opieka+nad+noworokami\&S.Name $=$ N01 + POR $\%$ C3 $\% 93 \mathrm{D}+*$ \&S.Catalog $=1 \mathrm{a} \& S$. Year $=0 \& S . S e l e c t e d T a b=$ MedicalData\&search $=$ true\# (accessed on 19 February 2021).

14. World Health Organization. WHO Statement on Caesarean Section Rates; World Health Organization: Geneva, Switzerland, 2015.

15. Gajewska, D.; Gudej, S. Zwyczaje żywieniowe i stan odżywienia kobiet a długość wyłącznego karmienia piersią. Znaczenie karmienia piersią-ocena świadomości wśród kobiet. Stand. Med. Pediatr. 2018, 15, 860-877.

16. Tracz, J.; Gajewska, D. Factors Influencing the Duration of Breastfeeding among Polish Women. J. Mother Child. 2020, 1, 39-46.

17. Główny Urząd Statystyczny Miasta w Liczbach. 2016. Available online: https://stat.gov.pl/obszary-tematyczne/inneopracowania/miasta-wojewodztwa/miasta-w-liczbach-2016,3,8.html (accessed on 16 February 2021).

18. Pracujacy i Wynagrodzenia w Gospodarce Narodowej w 2018 r.-Dane Ostateczne. Available online: https: / / stat.gov.pl/obszarytematyczne/rynek-pracy/pracujacy-zatrudnieni-wynagrodzenia-koszty-pracy/pracujacy-i-wynagrodzenia-w-gospodarcenarodowej-w-2018-roku-dane-ostateczne,17,3.html (accessed on 20 March 2021).

19. World Health Organization. Body Mass Index-BMI. Available online: http://www.euro.who.int/en/health-topics/diseaseprevention/nutrition/a-healthy-lifestyle/body-mass-index-bmi (accessed on 14 February 2021).

20. Kluj, P.; Gaszyński, T. Różnicowanie wybranych odrębności anatomicznych i fizjologicznych dziecka w stanie zagrożenia życia, terminologia, drogi oddechowe, oddychanie. Ostry Dyżur 2014, 7, 469-472.

21. World Health Organization. Indicators for Assessing Breastfeeding Practices: Reprinted Report of an Informal Meeting 11-12 June 1991, Geneva, Switzerland; World Health Organization: Geneva, Switzerland, 1991.

22. Paksoy Erbaydar, N.; Erbaydar, T. Relationship between Caesarean Section and Breastfeeding: Evidence from the 2013 Turkey Demographic and Health Survey. BMC Pregnancy Childbirth 2020, 20, 55. [CrossRef]

23. Hobbs, A.J.; Mannion, C.A.; McDonald, S.W.; Brockway, M.; Tough, S.C. The Impact of Caesarean Section on Breastfeeding Initiation, Duration and Difficulties in the First Four Months Postpartum. BMC Pregnancy Childbirth 2016, 16, 90. [CrossRef] [PubMed]

24. Prior, E.; Santhakumaran, S.; Gale, C.; Philipps, L.H.; Modi, N.; Hyde, M.J. Breastfeeding after Cesarean Delivery: A Systematic Review and Meta-Analysis of World Literature. Am. J. Clin. Nutr. 2012, 95, 1113-1135. [CrossRef] [PubMed]

25. Ahluwalia, I.B.; Li, R.; Morrow, B. Breastfeeding Practices: Does Method of Delivery Matter? Matern Child. Health J. 2012, 16, 231-237. [CrossRef]

26. Walasik, I.; Kosińska-Kaczyńska, K.; Kwiatkowska, K.; Roman, N.; Wysińska, J.; Szymusik, I. What Are Polish Women Afraid of in Vaginal Birth?-A Cross-Sectional Study. JMS 2020, 89, e489. [CrossRef] 
27. Lio, R.; Maugeri, A.; Rosa, M.; Cianci, A.; Panella, M.; Giunta, G.; Agodi, A.; Barchitta, M. The Impact of Socio-Demographic Factors on Breastfeeding: Findings from the "Mamma \& Bambino" Cohort. Medicina 2021, 57, 103. [CrossRef]

28. Rękas, M. Kobiety-Matki i Ich Powrót Na Rynek Pracy Po Urodzeniu Dziecka w Wynikach Badań. Zesz. Nauk. Wydziałowe Uniww. Ekon. W Katowicach 2013, 161, 122-131.

29. Economou, M.; Kolokotroni, O.; Paphiti-Demetriou, I.; Kouta, C.; Lambrinou, E.; Hadjigeorgiou, E.; Hadjiona, V.; Tryfonos, F.; Philippou, E.; Middleton, N. Prevalence of Breast-Feeding and Exclusive Breast-Feeding at $48 \mathrm{~h}$ after Birth and up to the Sixth Month in Cyprus: The BrEaST Start in Life Project. Public Health Nutr. 2018, 21, 967-980. [CrossRef]

30. Ogbo, F.A.; Eastwood, J.; Page, A.; Arora, A.; McKenzie, A.; Jalaludin, B.; Tennant, E.; Miller, E.; Kohlhoff, J.; Noble, J.; et al. Prevalence and Determinants of Cessation of Exclusive Breastfeeding in the Early Postnatal Period in Sydney, Australia. Int. Breastfeed. J. 2017, 12, 16. [CrossRef]

31. Chang, P.-C.; Li, S.-F.; Yang, H.-Y.; Wang, L.-C.; Weng, C.-Y.; Chen, K.-F.; Chen, W.; Fan, S.-Y. Factors Associated with Cessation of Exclusive Breastfeeding at 1 and 2 Months Postpartum in Taiwan. Int. Breastfeed. J. 2019, 14, 18. [CrossRef]

32. Bertini, G.; Perugi, S.; Dani, C.; Pezzati, M.; Tronchin, M.; Rubaltelli, F.F. Maternal Education and the Incidence and Duration of Breast Feeding: A Prospective Study. J. Pediatr. Gastroenterol. Nutr. 2003, 37, 447-452. [CrossRef]

33. Karall, D.; Ndayisaba, J.-P.; Heichlinger, A.; Kiechl-Kohlendorfer, U.; Stojakovic, S.; Leitner, H.; Scholl-Bürgi, S. Breast-Feeding Duration: Early Weaning-Do We Sufficiently Consider the Risk Factors? J. Pediatr. Gastroenterol. Nutr. 2015, 61, 577-582. [CrossRef] [PubMed]

34. Sarki, M.; Parlesak, A.; Robertson, A. Comparison of National Cross-Sectional Breast-Feeding Surveys by Maternal Education in Europe (2006-2016). Public Health Nutr. 2019, 22, 848-861. [CrossRef] [PubMed]

35. Logan, C.; Zittel, T.; Striebel, S.; Reister, F.; Brenner, H.; Rothenbacher, D.; Genuneit, J. Changing Societal and Lifestyle Factors and Breastfeeding Patterns Over Time. Pediatrics 2016, 137, e20154473. [CrossRef] [PubMed]

36. Heck, K.E.; Braveman, P.; Cubbin, C.; Chávez, G.F.; Kiely, J.L. Socioeconomic Status and Breastfeeding Initiation among California Mothers. Public Health Rep. 2006, 121, 51-59. [CrossRef]

37. Simko, M.; Totka, A.; Vondrova, D.; Samohyl, M.; Jurkovicova, J.; Trnka, M.; Cibulkova, A.; Stofko, J.; Argalasova, L. Maternal Body Mass Index and Gestational Weight Gain and Their Association with Pregnancy Complications and Perinatal Conditions. Int. J. Env. Res. Public Health 2019, 16, 1751. [CrossRef]

38. Poobalan, A.S.; Aucott, L.S.; Gurung, T.; Smith, W.C.S.; Bhattacharya, S. Obesity as an Independent Risk Factor for Elective and Emergency Caesarean Delivery in Nulliparous Women-Systematic Review and Meta-Analysis of Cohort Studies. Obes. Rev. 2009, 10, 28-35. [CrossRef]

39. Chen, C.-N.; Chen, H.-S.; Hsu, H.-C. Maternal Prepregnancy Body Mass Index, Gestational Weight Gain, and Risk of Adverse Perinatal Outcomes in Taiwan: A Population-Based Birth Cohort Study. Int. J. Environ. Res. Public Health 2020, 17, 1221. [CrossRef]

40. De Jersey, S.J.; Mallan, K.; Forster, J.; Daniels, L.A. A Prospective Study of Breastfeeding Intentions of Healthy Weight and Overweight Women as Predictors of Breastfeeding Outcomes. Midwifery 2017, 53, 20-27. [CrossRef]

41. Knight-Agarwal, C.R.; Rickwood, P.; To, S.; Jani, R. The Relationship between Maternal Pre-Pregnancy Body Mass Index and Exclusive Breastfeeding Initiation: Findings from an Australian Obstetric Cohort. Obes. Res. Clin. Pract. 2021, 15, 33-36. [CrossRef] [PubMed]

42. Garcia, A.H.; Voortman, T.; Baena, C.P.; Chowdhurry, R.; Muka, T.; Jaspers, L.; Warnakula, S.; Tielemans, M.J.; Troup, J.; Bramer, W.M.; et al. Maternal Weight Status, Diet, and Supplement Use as Determinants of Breastfeeding and Complementary Feeding: A Systematic Review and Meta-Analysis. Nutr. Rev. 2016, 74, 490-516. [CrossRef] [PubMed]

43. Szostak-Wegierek, D.; Waśkiewicz, A.; Piotrowski, W.; Stepaniak, U.; Pająk, A.; Kwaśniewska, M.; Nadrowski, P.; Niklas, A.; Puch-Walczak, A.; Drygas, W. Metabolic Syndrome and Its Components in Polish Women of Childbearing Age: A Nationwide Study. BMC Public Health 2018, 18, 15. [CrossRef]

44. Euro-Peristat Project European Perintal Health Report. Core Indicators of the Health and Care of Pregnant Women and Babies in Europe in 2015; Euro-Peristat: Paris, France, 2018.

45. Lande, B.; Andersen, L.F.; Bærug, A.; Trygg, K.U.; Lund-Larsen, K.; Veierød, M.B.; Bjørneboe, G.-E.A. Infant Feeding Practices and Associated Factors in the First Six Months of Life: The Norwegian Infant Nutrition Survey. Acta Pædiatrica 2003, 92, $152-161$. [CrossRef] [PubMed]

46. Kitano, N.; Nomura, K.; Kido, M.; Murakami, K.; Ohkubo, T.; Ueno, M.; Sugimoto, M. Combined Effects of Maternal Age and Parity on Successful Initiation of Exclusive Breastfeeding. Prev. Med. Rep. 2016, 3, 121-126. [CrossRef]

47. Al-Sahab, B.; Lanes, A.; Feldman, M.; Tamim, H. Prevalence and Predictors of 6-Month Exclusive Breastfeeding among Canadian Women: A National Survey. BMC Pediatr. 2010, 10, 20. [CrossRef] [PubMed]

48. Yngve, A.; Sjöström, M. Breastfeeding Determinants and a Suggested Framework for Action in Europe. Public Health Nutr. 2001, 4, 729-739. [CrossRef] 